\title{
Theory vs. Practice: Does Fiscal Policy Crowd Out Business Investment during Crises?
}

\author{
Sunwoo Yoo ${ }^{1}$ and Emma Campbell-Mohn\# \\ ${ }^{1}$ St. Johnsbury Academy Jeju, Jeju Special Self-Governing Province, 63644, Republic of Korea \\ \#Advisor
}

$\underline{\text { ABSTRACT }}$

In 2020, the South Korean government aimed to mitigate the socio-economic impact of the COVID-19 pandemic by enacting a fiscal stimulus package worth 66.8 trillion won. Traditional economic theory warns that such deficit-financed expansionary fiscal policies can have the adverse effect of crowding out business investment, but the current literature is more divided: some argue that the crowding-out effect outweighs the multiplier effect of fiscal stimulus; some claim that the two effects cancel each other out; and others assert that the scale of crowding out is small, at least in recessions. It is important to study the existence and scale of crowding out during recessions to evaluate the soundness of fiscal policies as a countercyclical tool. Thus, this paper examines whether Korea's fiscal policy crowded out business investment during two severe economic downturns: the "great recession" of 2008 and the "great lockdown" of 2020. The paper uses a cross-time case comparison of the two economic crises in the hopes of drawing generalizable conclusions for South Korea over time. The findings show that Korea's facility investment continued to increase during the recent pandemic but decreased during the 2008 financial crisis. Was this decrease due to crowding out? Further analysis suggests that the decrease in investment in 2008 was most likely a result of factors other than crowding out. Hence, the paper concludes that Korea's fiscal responses to the two crises did not crowd out business investment and thus encourages the continued use of appropriately sized and targeted fiscal stimulus during recessions.

\section{Introduction}

The United Nations' Framework for the Immediate Socio-Economic Response to COVID-19 (2020) warns that the current "pandemic is far more than a health crisis: it is affecting societies and economies at their core." Last year, as the number of confirmed cases surged at an alarming rate, numerous countries mandated strict social distancing policies and, in some cases, lockdowns. Unfortunately, these health prevention measures were not without cost: they resulted in a 14.3\% drop in the FTSE 100 index and, according to the International Labour Organization (2021), will contribute to a global unemployment of more than 200 million people by 2022 .

While it is true that COVID-19 presented novel challenges to today's globalized world, COVID-19 is neither the world's first pandemic nor the first global economic crisis. The COVID-19 pandemic claimed millions of lives, but the deadliest pandemic in modern history was the "Spanish flu" of 1918, which infected about one-third of the world's population and killed at least 50 million people (U.S. Center for Disease Control and Prevention, 2021). As for economic crises, the bursting of the U.S. housing bubble in 2007 led major financial institutions in advanced economies to file for bankruptcy, triggering the first global contraction since the Second World War that is also known as the global financial crisis (GFC). In the OECD area, world gross domestic product (GDP) fell by $4.7 \%$ between the first quarter of 2008 and the second quarter of 2009, and unemployment reached a post-war record of $8.7 \%$ (OECD, 2011).

In response to the GFC and the COVID-19 recession, many advanced economies implemented large-scale fiscal policies. In other words, the governments aimed to stimulate the economy by increasing their expenditures without increasing the tax rate. South Korea was no exception. Between 2008 and 2010, the Korean government 
enacted a fiscal stimulus package worth 5.9\% of its GDP - the highest ratio among the G20 nations (OECD, 2011). Similarly in 2020, the government implemented fiscal stimulus packages worth 66.8 trillion won, mainly as emergency relief funds to industries and demographics hardest hit by the pandemic (Korea Development Institute, 2021). The 2020 fiscal expenditure was equivalent to $3.5 \%$ of the nation's GDP (Park, 2021), which is not nearly as high as the expenditure-to-GDP ratio during the GFC, but it still caused Korea's budget deficit to triple from 22.3 trillion won in August 2019 to 70.9 trillion on in August 2020 (Ministry of Strategy and Finance, 2020).

Do expansionary fiscal policies work? One common concern is the crowding out of business investment. In the New Palgrave Dictionary of Economics (2008), Olivier Blanchard defines crowding out as "all the things which can go wrong when debt-financed fiscal policy is used to affect output." One notion a "debt-financed fiscal policy" may "go wrong" is by increasing the real interest rate. If the government wishes to increase its expenditure without increasing the tax rate, it must run a budget deficit. An increase in the budget deficit means a decrease in public savings, and as public savings is a constituent of the supply of loanable funds, the real interest rate decreases. This increased cost of borrowing will discourage firms from investing in their capital stock, which is critical for an economy's long-term growth. Due to this reason, many economists have raised doubts about the efficacy of expansionary fiscal policies, while others defend these policies by claiming that the scale of crowding out is small when the economy is in recession.

This paper aims to shed light on the discussion of fiscal policies as a countercyclical tool by investigating whether expansionary fiscal policies during a severe recession crowded out business investment. Since numerous advanced economies have implemented expansionary fiscal policies to weather the recent economic downturns, it is imperative to study the short-term and long-term consequences of these policies. Even if expansionary fiscal policies successfully stimulate the economy in the short-term, they would not be an optimal countercyclical measure if they also crowd out business investment and thereby decrease the nation's capital formation in the long-term.

To examine these issues, this paper uses a cross-time case comparison of the GFC and the COVID-19 crisis in South Korea. By utilizing a cross-time case comparison, the study hopes to draw generalizable conclusions for South Korea over time, and by focusing on South Korea, it hopes to examine the impact of global economic downturns on a small open economy that relies heavily on trade. In the following sections, this paper compares and contrasts the Korean government's fiscal response to the GFC and COVID-19. Then, it examines how facility investment changed during and after each crisis and suggests several factors that could have contributed to these changes. The findings show that Korea's facility investment continued to increase during the recent pandemic but decreased during the GFC. However, further analysis suggests that the decrease in investment during the GFC was due to factors other than crowding out, such as a decline in business confidence. Hence, the paper concludes that Korea's fiscal responses to the GFC and COVID-19 did not crowd out business investment and thus encourages the continued use of appropriately sized and targeted expansionary fiscal policies as countercyclical measures.

\section{Literature Review}

To understand the role of fiscal policies in crises and their long-term impacts on business investment, it is crucial to examine the current literature. The idea of using expansionary fiscal policies as a countercyclical tool is largely based on the Keynesian theory. In his book (1936), John Maynard Keynes argues that, in a recession, government intervention can stabilize the economy. He proposes that the government should increase its spending and/or decrease taxes to increase the aggregate demand. With government spending creating a multiplier effect, the stimulus will increase the aggregate demand and restore the economy to its original level of output more quickly than it would in a free market. However, neoclassical economists oppose the use of expansionary fiscal policy, pointing to the potential crowding out effect. For instance, the Nobel Laureate Milton Friedman (1969) suggests that the crowding out effect of deficit-financed fiscal stimulus outweighs the multiplier effect. He states that the state of government budget has "a considerable effect on interest rates": a deficit-financed fiscal policy "tends to raise interest rates," but if the government runs a budget surplus, the interest rates tend to drop, crowding in investment. Friedman gives the example of 
the Tax Reform Act of 1969, which temporarily increased the income tax surcharge rate to 5\% and, according to him, caused the interest rates to drop. The fiscal policies this paper will examine is slightly different form the 1969 Tax Reform Act in that they increased the government's expenditure without increasing the tax rates.

Since many countries implemented massive fiscal stimulus packages in response to the GFC, copious amounts of research have focused on the impact of expansionary fiscal policy over time on creating high levels of government debt, which can affect economic growth. One notable study by Carmen Reinhart and Kenneth Rogoff (2010) analyzes the relationship between government debt and the real GDP growth of 20 advanced economies from 1946 to 2009. It finds that, when the public-debt-to-GDP ratio exceeds 90 percent, real GDP growth drops sharply to zero or slightly negative. However, a critique by Thomas Herndon et al (2013) contend that Reinhart and Rogoff's estimation is seriously influenced by methodological errors. According to their "proper" calculation, "average GDP growth at debt/GDP ratios over 90 percent is not dramatically different than when debt/GDP ratios are lower."

In South Korea, the expansionary fiscal policies in response to the Great Recession raised concerns regarding their possible crowding out effect. For instance, Seoul National University professor Inho Lee stated in a recent interview with the Monthly Chosun Magazine, "the idea of increasing government expenditure to stimulate consumer spending is extremely dangerous" (Chung, 2020). He warned that fiscal stimulus without a clear purpose, such as emergency relief funds, is like "squandering money as if there is no tomorrow." His argument is that, even if the fiscal stimulus boosts economic activity, the crowding out effect will counter the economic stimulus. In other words, what the government does with its fiscal stimulus is produce what the private sector would have otherwise produced, but with increased public debt. However, a report from the Korea Economic Research Institute (Seol \& Kim, 2011) finds that this concern is unfounded, at least for large conglomerates. They show that large conglomerates increased their physical capital by $7.5 \%$ in 2009-2010, which is more than double the 3.3\% increase in 2001-2007. Furthermore, large conglomerates increased their R\&D expenditures even during the GFC. Although this report focuses on large conglomerates only, a recent study examines the trends in aggregate business investment after the GFC (Jang, 2020). The study proposes that business investment had been steadily declining since the early 2000s, and the GFC did not accelerate this decline. Also, a study examining the effectiveness of the fiscal policies during the GFC with regards to crowding out argues that the monetary policies successfully accommodated the fiscal stimulus and thereby limited the crowding out of private investment (Pyun \& Rhee, 2014).

As with the GFC, the recent recession linked to COVID-19 generated concerns about the rise in public debt caused by expansionary fiscal policies. Although South Korea's fiscal response to the crisis has been lauded by the IMF (2021) for lessening the economic impact of the pandemic, there are still concerns about the long-term effects. Makin and Allan (2020) examine how the fiscal response to COVID-19 increased the size of government deficits and debts across the world and highlight how this increases future macroeconomic risks, including a possible crowding out of business investment. They also compare the policies enacted during the GFC and COVID-19 and conclude that the policy responses are not similar in nature: while the global response to the GFC follows the Keynesian prescription of fiscal stimulus, the global response to the COVID-19 recession is more focused on tax relief measures. Although this paper agrees with Makin and Allan that there are dissimilarities between the fiscal policies enacted during the GFC and those enacted during the COVID-19 recession, it considers them similar enough to be compared, since they both significantly increased the government's budget deficit.

Based on the above studies, it is imperative to examine the extent to which expansionary fiscal policies crowd out private investment to evaluate which policies are appropriate in economic crises. This paper will, therefore, conduct a cross-time case comparison of the GFC and the COVID-19 to better understand the impact of fiscal policy in business investment.

\section{Case Studies}

\section{Introduction to the Cases}


The "great recession" of 2008 and the ongoing "great lockdown" are undeniably different crises. As Paul Krugman (2021) explained in his interview with Ezra Klein, the current crisis "does not fit into the normal typology" of recessions and is rather similar to a natural disaster. For instance, the GFC began with the collapse of financial institutions and assets, while the COVID-19 crisis is a pandemic-induced economic recession. In other words, the two crises have vastly different causes and routes of transmission.

Nonetheless, there are similarities in how governments responded to the economic impact of crises. The GFC is arguably the best precedent for the current crisis when studying the Korean government's fiscal policy response to a severe recession. In fact, the GFC was the only economic crisis in Korea's modern history in which the government enacted discretionary fiscal policies. During the Asian financial crisis of 1997, for example, the Korean government executed an IMF-supported structural reform (Kim, 2006). In other words, instead of providing deficit-financed stimulus checks, the government restructured the balance sheets of financial institutions with the IMF's bailout. Thus, although the GFC and the COVID-19 crisis are dissimilar in nature, they are the best two examples of the Korean government's fiscal response to a global recession in recent history.

\section{The Global Financial Crisis}

The GFC was a period of extreme stress in global financial markets and banking systems from 2007 to 2009 . The crisis began with the collapse of the U.S. housing market in the summer of 2007 and spread to many other advanced economies and later to developing countries. An analysis from the OECD (2010) compares the crisis to an overflow of a dam: easy access to cheap borrowing caused the prices of housing and other assets to rise to "levels that were going to be hard to sustain over the long term." Low interest rates and inflation rates in the U.S. made mortgages cheap, encouraging buyers to jump into the market and fulfill their "American dream" of owning a house. In the years leading up to the crisis, this easy access to borrowing fueled a bubble in the U.S. housing market, like filling up a dam with water. However, while channels can be dug into a real dam to ease the pressure of water, the channels dug into the housing bubble only exacerbated the problem. The channels were "poor regulation," which created incentives for financial institutions to engage in risky money-making activities.

A report by the Financial Crisis Inquiry Commission (2011) agrees that the lack of financial regulation contributed to the GFC. It concludes the financial crisis "was avoidable," but the "captains of finance and the public stewards of [the U.S.] financial system" chose to ignore and discount the numerous red flags, often because they "lacked the political will" to challenge the wealthy and powerful financial institutions. Firstly, the report identifies that the government's lack of financial regulation made the U.S. financial market unstable. In the 1980s, President Ronald Reagan and Alan Greenspan, the then chair of the Federal Reserve, promoted self-regulation of financial institutions. Nobel Laureate Paul Krugman even describes Reagan and his advisers as the "prime villains" behind the GFC in his New York Times column entitled "Reagan Did It" (2009). Krugman asserts that the Reagan administration "essentially ended the New Deal restrictions on mortgage lending," which were implemented after the Great Depression to restrain household's ability to purchase mortgages without putting down a substantial amount of money. In the award-winning documentary Inside Job (2010), George Soros, the chairman of the Soros Fund Management, explains that the financial regulations put in place after the Great Depression were like the compartments in an oil tanker. Without the watertight compartments, the oil would slosh around the massive boat and cause it to capsize, and without appropriate regulations, the financial institutions of Wall Street grew out of hand. For example, the U.S. Securities and Exchange Commission (SEC) relaxed the leverage ratios for investment banks in April 2004, allowing the banks to sharply increase their borrowings even when they had little capital at hand to repay them. As a result, as of 2007 , the leverage ratios at the five major investment banks were as high as 40 to 1 , which meant that for every $\$ 40$ in assets, there was only $\$ 1$ in capital to cover for losses (Financial Crisis Inquiry Report, 2011).

The lack of financial regulation cleared the way for financial institutions to borrow excessively and engage in risky trading activities. The Financial Crisis Inquiry Report identifies the failure of "corporate governance and risk management" at several key financial institutions. According to the report, the growth of securitization in the years 
leading up to the crisis created a new "pipeline" of home buyers, lenders, investment banks, and investors. Shortly after the home buyers signed the documents and received their keys, the lenders sold their mortgages to investment banks, who would "package, slice, repackage, insure, and s[ell]" them as "incomprehensibly complicated" mortgagebacked securities (MBS). The investment banks then paid credit rating agencies - Moody's, Standard and Poor's, and Fitch -- to rate their MBS in terms of their quality and safety before selling them to investors around the globe. The investment banks incentivized the rating agencies to offer high ratings, and as a result, Moody's rated nearly 45,000 mortgage-related securities as triple-A, which meant that they were as safe as the U.S. Treasury bonds. Moreover, the investment banks bundled the lowly-rated MBS with other loans, such as student loans and credit card debt, and repackaged them into collateralized debt obligations (CDOs), on which the rating agencies would then give higher ratings. The Oscar-nominated film The Big Short (2015) explains that CDOs are like mixing a three-day-old halibut that didn't sell with other ingredients and cooking a seafood stew for sale. As the MBS and CDOs became popular, lenders increased home loans to people with weak credit records, or subprime mortgages. Often, the lenders did not even verify the borrowers' stated income since the risk of mortgage defaults would soon be passed onto the investment banks and then to investors. As the OECD analysis (2011) puts it, the financial market's "ever-increasing thirst for short-term profits" prompted many people to turn a blind eye to long-term risks. As a result, the number of subprime mortgages almost doubled from 1.1 million in 2003 to 1.9 million in 2005 (Federal Reserve Board, 2008).

Consequently, when the Federal Reserve started increasing the interest rates in 2004 to fight inflation, households were unable to pay their mortgage interests; the share of "seriously delinquent" mortgage loans increased from $2.4 \%$ in 2002 to $4.5 \%$ in the second quarter of 2008 , and foreclosures rose to about 1.2 million in the first half of 2008 (Federal Reserve Board, 2008). With the increase in the supply of houses and a decrease in demand, housing prices plummeted. This bursting of the U.S. housing bubble led to the bankruptcy of several major financial institutions. On September $15^{\text {th }}, 2009$, the fourth-largest U.S. investment bank Lehman Brothers filed for bankruptcy. Other investment banking companies, including Merrill Lynch and Morgan Stanley, needed to be bailed out by the government.

The collapse of the U.S. financial market quickly spread to other developed countries whose investment banks were exposed to MBS and other "toxic" assets. OECD member states experienced an economic contraction of $4.7 \%$ between the first quarter of 2008 and the second quarter of 2009, and unemployment reached a post-war record of $8.7 \%$. According to the World Trade Organization (2021), total merchandise exports grew steadily by an average in the 10 years leading up to the crisis until it fell by $12 \%$ in 2009. This drop in world trade, according to the OECD, not only reflected the impact of the emerging crisis but also exacerbated the situation; world trade decreased as a result of decreased consumer demand and increased difficulty for exporters to acquire loans, leading to a worldwide recession, especially impacting emerging and developing countries.

Although Korea's financial institutions had limited exposure to the toxic assets, the country suffered massive impacts in the financial market and real economy. With the collapse of the Lehman Brothers in September 2009, panicked financial institutions around the world withdrew their assets from overseas banks (Korea Economic Research Institute, 2009). As a result of this capital flight, the Korean won (KRW) appreciated by $19.9 \%$ against the USD between September and December 2009. The appreciation of KRW was noticeably higher than that of other currencies, such as the Singaporean dollar, which only appreciated by about 3.1\% in the same period. Korea's other assets, most notably stocks, also decreased in value. For instance, the Korea Composite Stock Price Index (KOSPI) and the Korean Securities Dealers Automated Quotations (KOSDAQ) decreased by 30.0\% and 32.2\%, respectively, from October to December. The impact of the GFC on Korea's real economy is shown through the steep decline in net exports. According to a KERI report (Heo et al, 2009), Korea's net exports rose steadily by about $20 \%$ each quarter in the years leading up to the crisis, but in the fourth quarter of 2008 and the first quarter of 2009 , exports fell by $9.9 \%$ and $25.2 \%$, respectively. Considering these steep changes in exchange rate, stocks values, and exports, the IMF adjusted its 2009 growth outlook for Korea from 4.3\% in July 2008 to $-4.0 \%$ in January 2009 -- the lowest among G20 nations.

However, the Korean economy fared better than the IMF predicted and emerged more quickly from the crisis than other countries did. As the financial market stabilized and exports recovered, the GDP grew by over $8 \%$ between 
the second quarter of 2009 and the first quarter of 2010. In fact, Korea's GDP growth rate in 2010 was $6.2 \%$, which is noticeably higher than the world average of $4.3 \%$. Furthermore, Korea was one of the three OECD member states to avoid both an economic slowdown and an increase in unemployment during the crisis (OECD, 2010).

According to the KDI (Cho \& Kim, 2011), such a quick and swift recovery could be partly attributed to the government's aggressive fiscal response to the crisis. From 2008 to 2009, the Korean government implemented a fiscal stimulus package worth 43.7 trillion won, which was the largest since the Asian financial crisis of the 1990s. In 2008 , the size of the fiscal package was equivalent to $1.1 \%$ of the GDP, and this ratio was equal to that of the U.S. In 2009, Korea's fiscal expenditure was 3.7\% of its GDP, which was second highest among the G20 nations (IMF, 2009). Between 2008 and 2009, the government implemented three sets of fiscal policies to weather the impact of the GFC: the 2008 supplementary budget, 2009 budget proposal, and 2009 supplementary budget. Table 1 summarizes the size and purpose of each set:

Table 1. A summary of the 2008 supplementary budget, 2009 budget proposal, and 2009 supplementary budget.

\begin{tabular}{|c|c|c|c|c|}
\hline & \\
\hline & & $\begin{array}{l}2008 \quad \text { Supplementary } \\
\text { Budget }\end{array}$ & 2009 Budget Proposal & $\begin{array}{l}2009 \text { Supplementary } \\
\text { Budget }\end{array}$ \\
\hline \multicolumn{2}{|l|}{ Size } & 4.6 trillion won & 10.7 trillion won & $\begin{array}{l}28.4 \text { trillion won } \\
\text { (spending } 17.2 \text { ) }\end{array}$ \\
\hline \multicolumn{2}{|l|}{ Purpose } & $\begin{array}{l}\text { To revive consumer } \\
\text { spending after a rise in } \\
\text { oil prices }\end{array}$ & $\begin{array}{l}\text { To overcome the eco- } \\
\text { nomic downturn and re- } \\
\text { vitalize local economy }\end{array}$ & $\begin{array}{l}\text { To support job mainte- } \\
\text { nance, expand employ- } \\
\text { ment opportunities, and } \\
\text { stabilize public welfare }\end{array}$ \\
\hline \multirow{5}{*}{$\begin{array}{l}\text { Main Areas } \\
\text { of Spend- } \\
\text { ing }\end{array}$} & $\begin{array}{l}\text { Revitalizing provin- } \\
\text { cial economy }\end{array}$ & $\begin{array}{l}1.0 \text { trillion won, includ- } \\
\text { ing social overhead cap- } \\
\text { ital (SOC) }\end{array}$ & $\begin{array}{l}4.6 \text { trillion won, includ- } \\
\text { ing SOC }\end{array}$ & 3.5 trillion won \\
\hline & $\begin{array}{l}\text { Stabilizing the live- } \\
\text { lihood of low-in- } \\
\text { come households }\end{array}$ & $\begin{array}{l}1.3 \text { trillion won, includ- } \\
\text { ing gas price tax rebate }\end{array}$ & 1.0 trillion won & 4.1 trillion won \\
\hline & $\begin{array}{l}\text { Supporting SMEs } \\
\text { and the self-em- } \\
\text { ployed }\end{array}$ & $\begin{array}{l}0.4 \text { trillion won, includ- } \\
\text { ing aid to farmers and } \\
\text { fishermen for fuel costs }\end{array}$ & 3.4 trillion won & 4.5 trillion won \\
\hline & $\begin{array}{l}\text { Tackling unemploy- } \\
\text { ment }\end{array}$ & - & 0.3 trillion won & 2.8 trillion won \\
\hline & Other & $\begin{array}{l}\text { Subsidies for energy re- } \\
\text { duction and investment } \\
\text { in medium to long-term } \\
\text { energy acquisition }\end{array}$ & $\begin{array}{l}5.6 \text { trillion won on ex- } \\
\text { change equalization } \\
\text { fund }\end{array}$ & $\begin{array}{l}2.3 \text { trillion won on } \\
\text { green growth and other } \\
\text { future-oriented invest- } \\
\text { ments }\end{array}$ \\
\hline
\end{tabular}

Data from the Republic of Korea's Ministry of Strategy and Finance, 2021.

Despite the unprecedented scale of fiscal expenditure, the expansionary fiscal policies do not appear to have crowded out business investment. Although business investment did decrease during the crisis, this decrease can be attributed to other factors. For instance, capital investment decreased by $0.2 \%$ in 2008 and $8.1 \%$ in 2009 . Although 
the annual growth in capital investment had been fluctuating in the years leading up to the crisis, it was not until 2008 that the growth became negative. However, it is unlikely that this decrease is a result of the expansionary fiscal policies. For expansionary fiscal policies to crowd out business investment, the increased fiscal expenditure must increase the real interest rate and thereby increase firms' cost of borrowing. However, as Figure 1 demonstrates, Korea's real interest rate decreased during the GFC. The decline in real interest rate reflects the Bank of Korea's (BOK) monetary policies in response to the crisis. From August 2008 to February 2009, the BOK aimed to increase the money supply and stimulate the economy by lowering the base rate from $5.25 \%$ to $2.00 \%$. Even after the BOK withdrew its monetary policies and the base rate increased, the real interest remained at its pre-crisis levels until 2014. Thus, it is likely that the BOK's monetary policies and low inflation rate prevented the real interest rate from rising despite the government's immense fiscal expenditures, thereby preventing the crowding out of business investment.

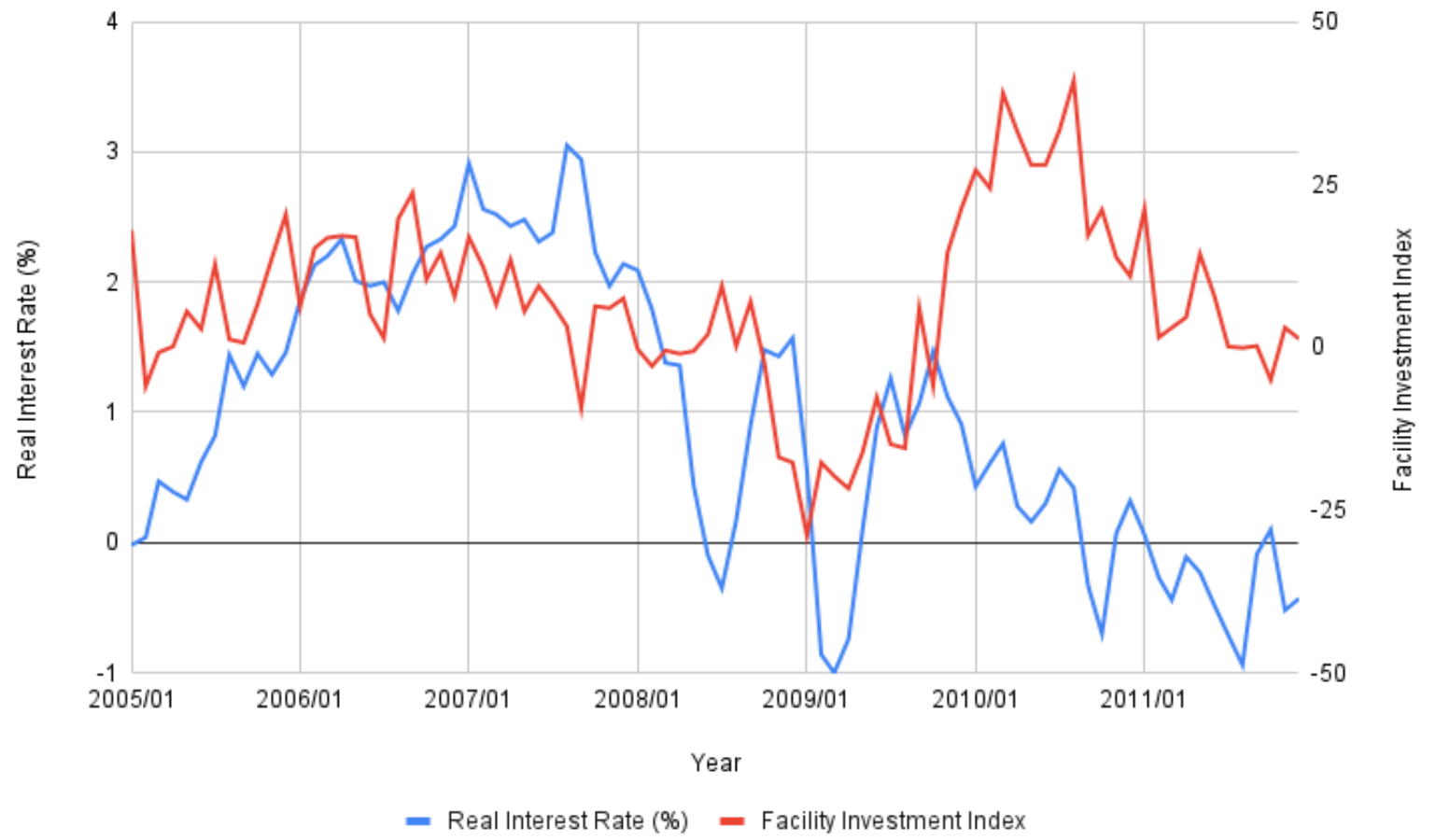

Figure 1. Real Interest Rate and Facility Investment during the GFC. The blue line graph represents the real interest rate $(\%)$, which was calculated by subtracting the percent change in the consumer price index from the fixed deposit rate. The red line graph represents the facility investment index.

Data from the Bank of Korea Economic Statistics System, 2021.

If it wasn't the expansionary fiscal policies, what caused the decrease in capital investment in 2008 and 2009 ? One probable explanation for the decline in capital investment is that business confidence decreased. As written in the textbook Principles of Economics, firms tend to spend more on investment when business confidence is high, since they believe "that the future payoff from the investment will be substantial." Conversely, when business confidence drops, business investment declines (Mankiw, 2009). Figure 2 illustrates Korea's facility investment and business confidence -- represented as the BOK's Business Survey Index (BSI) -- during the GFC. 


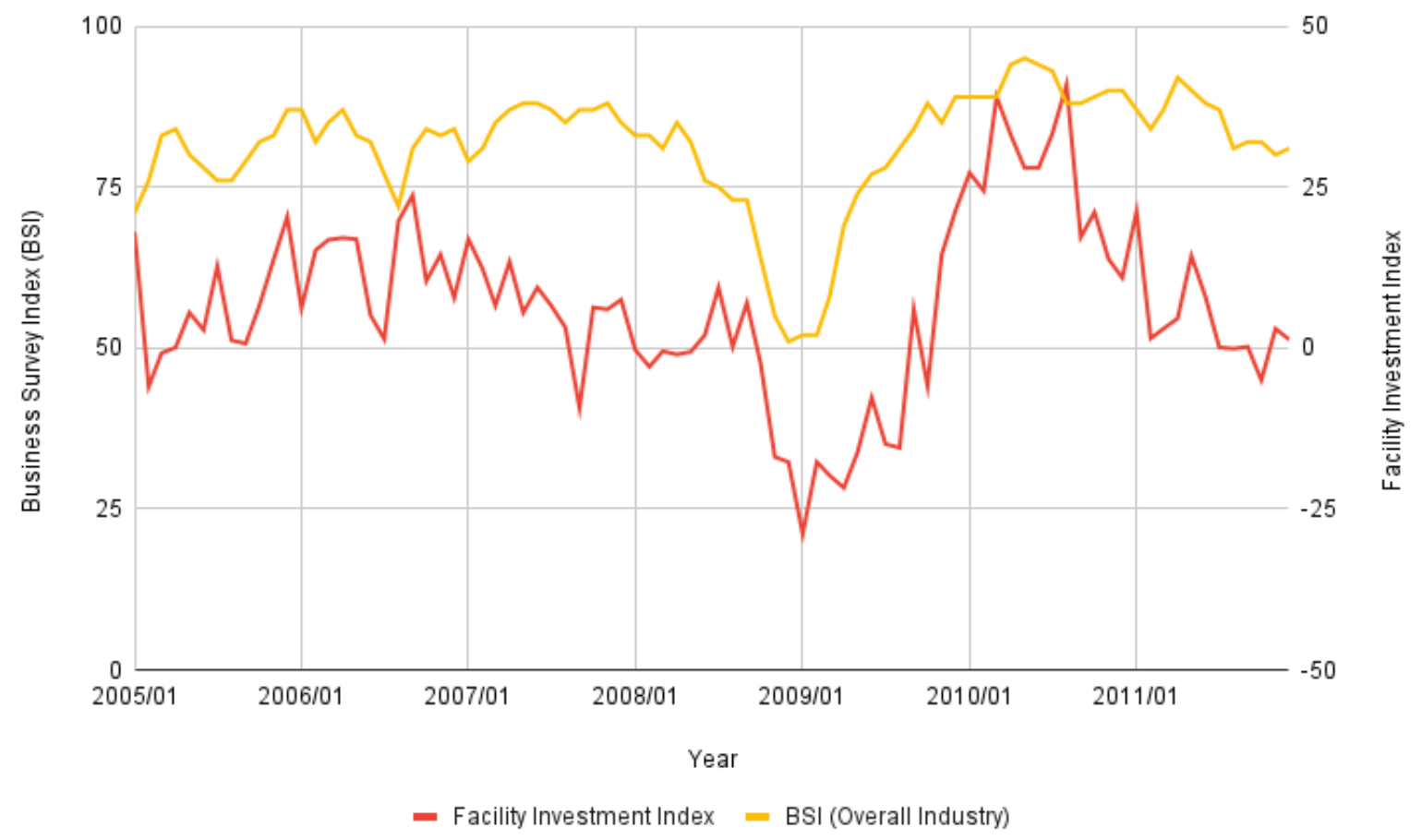

Figure 2. Business Confidence and Facility Investment Index during the GFC. The yellow line graph represents the BSI for overall industry, and the red line graph represents the facility investment index.

Data from the Bank of Korea Economic Statistics System, 2021.

\section{COVID-19}

When COVID-19 hit South Korea, foreign media lauded the government for its timely and transparent effort to contain the outbreak. Instead of resorting to lockdowns, the Korean government pursued a systematic response consisting of extensive testing, tracing, and treatment (3Ts) strategy to "flatten the curve." According to a Wall Street Journal article, this blending of technology and testing helped the country "halt virus transmission better than any other wealthy country during the pandemic's early months" (Martin \& Yoon, 2020). Thanks to such effective healthcare measures, the Korean government was able to not only contain the spread of the virus but also limit its economic impact. The article writes, "South Korea never had to mandate a lockdown, so restaurants and businesses were able to stay open, cushioning the blow to the economy." The IMF's annual assessment of Korea's economy (2021) similarly commented that the government's effective containment strategy and comprehensive economic response "helped make the downturn the smallest among advanced G20 economies." Indeed, Korea's real GDP growth in 2020 was $0.9 \%$, while the world average was $-3.5 \%$ (IMF, 2021).

However, although the pandemic had a comparatively small impact on Korea's aggregate economy, it had severe consequences in employment and consumer spending. According to a recent report from the KERI (2021), the COVID-19 crisis has resulted in an additional unemployment of about 460 thousand people and a fall in consumer spending by $7.41 \%$ in Korea. This drop in employment and consumer spending is larger than those in the GFC, during the peak year of which employment and consumer spending decreased by 311 thousand people and $3.2 \%$, respectively. In other words, while the impact on real GDP was similar to that during the GFC, the impacts on employment and consumer spending were significantly greater. The report suggests the reason for this disparity could be found in the nature of the crisis: the industries hit hardest by the fear of the infection and social distancing measures were those providing face-to-face services, and these industries have higher employment multipliers, which means that an 
increase in unemployment in these industries have larger ripple effects for the whole economy. Indeed, while some industries suffered severe economic losses, some even prospered during the crisis; the culture, hospitality, and passenger transportation industries contracted by around $20 \%$, whereas finance and IT industries showed positive growth. Furthermore, while the manufacturing sector contracted by an average of $5 \%$, the semiconductor industry grew by $23 \%$ (KIET, 2020). In fact, the statistical variance of growth across industries during the current crisis is about 2.5 times higher than that during the GFC (KIET, 2021). In addition to varying impacts of the pandemic, the Korean economy is witnessing an uneven recovery across sectors. The IMF annual assessment points out that Korean exports have rebounded, whereas services and consumption remain below pre-pandemic levels, creating a "K-shaped" recovery.

Due to this uneven impact across sectors, the Korean government's fiscal policies were often targeted towards the industries and demographics hardest hit by the pandemic. In 2020, the government passed four supplementary budgets. In total, these supplementary budgets were worth 66.8 trillion won. Such aggressive supplementary budgets continued in 2021 . While the tax revenue only increased by $0.2 \%$ this year, the government plans to increase its total expenditure by $8.9 \%$, and in March 2021, the Congress passed the first supplementary budget of the year worth 14.9 trillion won (KDI, 2021). Table 2 summarizes the size and purpose of each supplementary budget:

Table 2. A summary of the four supplementary budgets passed in 2020 .

\begin{tabular}{|c|c|c|c|c|c|}
\hline & $\begin{array}{l}\text { 1st Supplementary } \\
\text { Budget }\end{array}$ & $\begin{array}{l}\text { 2nd Supplemen- } \\
\text { tary Budget }\end{array}$ & $\begin{array}{l}\text { 3rd Supplemen- } \\
\text { tary Budget }\end{array}$ & $\begin{array}{l}\text { 4th Supplemen- } \\
\text { tary Budget }\end{array}$ \\
\hline \multicolumn{2}{|l|}{ Size } & 11.7 trillion won & 12.2 trillion won & 35.1 trillion won & 7.8 trillion won \\
\hline \multicolumn{2}{|l|}{ Purpose } & $\begin{array}{l}\text { To minimize the } \\
\text { impacts of } \\
\text { COVID-19 and to } \\
\text { overcome the cri- } \\
\text { sis quickly }\end{array}$ & $\begin{array}{l}\text { To stabilize peo- } \\
\text { ple's livelihood } \\
\text { and income, and to } \\
\text { stimulate con- } \\
\text { sumer spending }\end{array}$ & $\begin{array}{l}\text { To quickly over- } \\
\text { come the eco- } \\
\text { nomic crisis and to } \\
\text { prepare for the } \\
\text { post-COVID era }\end{array}$ & $\begin{array}{l}\text { To offer custom- } \\
\text { ized aid to the de- } \\
\text { mographics hard- } \\
\text { est hit by the pan- } \\
\text { demic }\end{array}$ \\
\hline \multirow{4}{*}{$\begin{array}{l}\text { Main Ar- } \\
\text { eas of } \\
\text { Spending }\end{array}$} & $\begin{array}{l}\text { Strengthening } \\
\text { the public health } \\
\text { emergency re- } \\
\text { sponse system }\end{array}$ & 2.3 trillion won & - & 2.4 trillion won & 0.2 trillion won \\
\hline & $\begin{array}{l}\text { Revitalizing pro- } \\
\text { vincial economy }\end{array}$ & 0.8 trillion won & - & 0.2 trillion won & - \\
\hline & $\begin{array}{l}\text { Supporting } \\
\text { SMEs and small } \\
\text { business owners }\end{array}$ & 2.4 trillion won & - & 1.9 trillion won & 3.9 trillion won \\
\hline & $\begin{array}{l}\text { Stabilizing the } \\
\text { people's liveli- } \\
\text { hood and unem- } \\
\text { ployment }\end{array}$ & 3.0 trillion won & $\begin{array}{l}7.6 \text { trillion won as } \\
\text { emergency relief } \\
\text { funds to the bot- } \\
\text { tom } 70 \% \text { house- } \\
\text { holds of the in- } \\
\text { come bracket }\end{array}$ & 10.0 trillion won & $\begin{array}{l}1.9 \text { trillion won } \\
\text { (1.5 on emergency } \\
\text { employment mar- } \\
\text { ket stabilization } \\
\text { and } 0.4 \text { emergency }\end{array}$ \\
\hline
\end{tabular}




\begin{tabular}{|l|l|l|l|l|l|}
\hline & & & & $\begin{array}{l}\text { aid to low-income } \\
\text { households })\end{array}$ \\
\cline { 2 - 5 } & Other & $\begin{array}{l}1.7 \text { trillion won on } \\
\text { special aid to the } \\
\text { Daegu-Gyeong- } \\
\text { buk area }\end{array}$ & - & $\begin{array}{l}5.1 \text { trillion won on } \\
\text { the Korean New } \\
\text { Deal }\end{array}$ & $\begin{array}{l}1.8 \text { trillion won on } \\
\text { care services }\end{array}$ \\
\hline
\end{tabular}

Source: The Republic of Korea's Ministry of Strategy and Finance, 2021.

According to the KDI (Lee et al, 2021), these fiscal expenditures were effective at mitigating the impact of the crisis and stimulating economic growth. The institute estimates the multiplier effect of the five supplementary budgets so far to be $0.5 \%$ in 2020 and $0.3 \%$ in 2021 and that for a one-won increase in fiscal expenditure, the real GDP grew by $0.2 \sim 0.3$ won. The reason the multiplier effect is relatively small is probably due to the fact that many of the fiscal policies were specifically targeted at providing financial aid to the industries and demographics hardest hit by the pandemic rather than at increasing production. According to the KDI's measure of fiscal stance (FIS), the Korean government's fiscal response to the COVID-19 crisis was much more expansionary than its response to the GFC. However, compared to other countries, the size of Korea's fiscal package was small. For instance, according to the IMF, countries that experienced a high number of infections -- such as the U.S., U.K., Germany, and Japan implemented fiscal packages worth more than $10 \%$ of the GDP, whereas Korea's fiscal package was equivalent to only about $3.4 \%$ of its GDP.

Surprisingly, despite these expansionary fiscal policies, capital investment continued to increase, especially among large conglomerates. The KDI report (2021) states that "equipment investment maintained high growth led by machinery, and leading indicators sustained favorable conditions." As can be seen from the Figures 3 and 4 below, equipment investment maintained its upward trend even when business confidence, as indicated by the business survey index (BSI), plummeted in early 2020. Although construction investment decreased, it has been on a steady decline since 2017, and the pandemic does not appear to have accelerated this trend. 


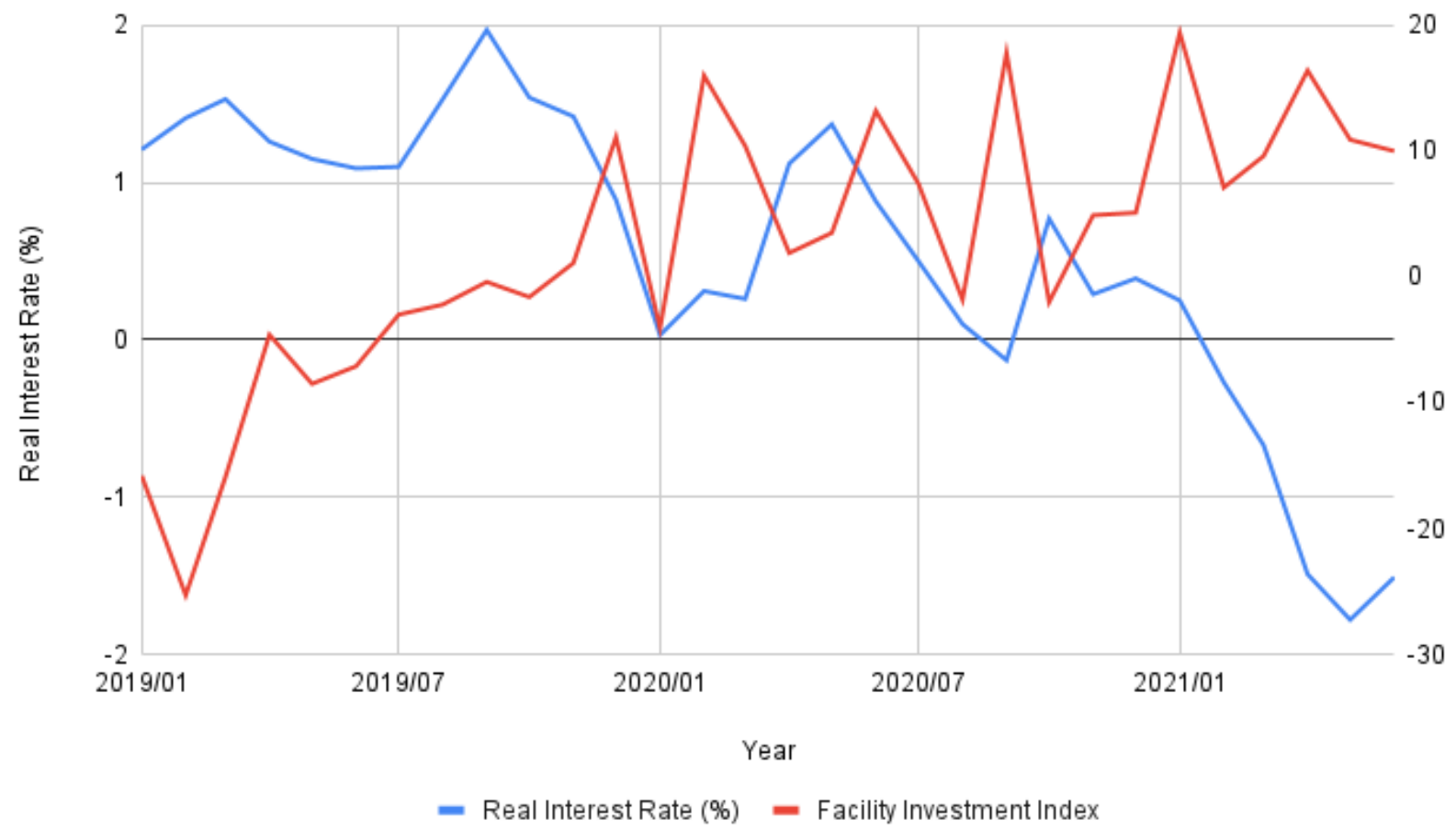

Figure 3. Real Interest Rate and Facility Investment Index during the COVID-19 Recession. The blue line graph represents the real interest rate (\%), which was calculated by subtracting the percent change in the consumer price index from the fixed deposit rate. The red line graph represents the facility investment index.

Data from the BOK Economic Statistics System, 2021.

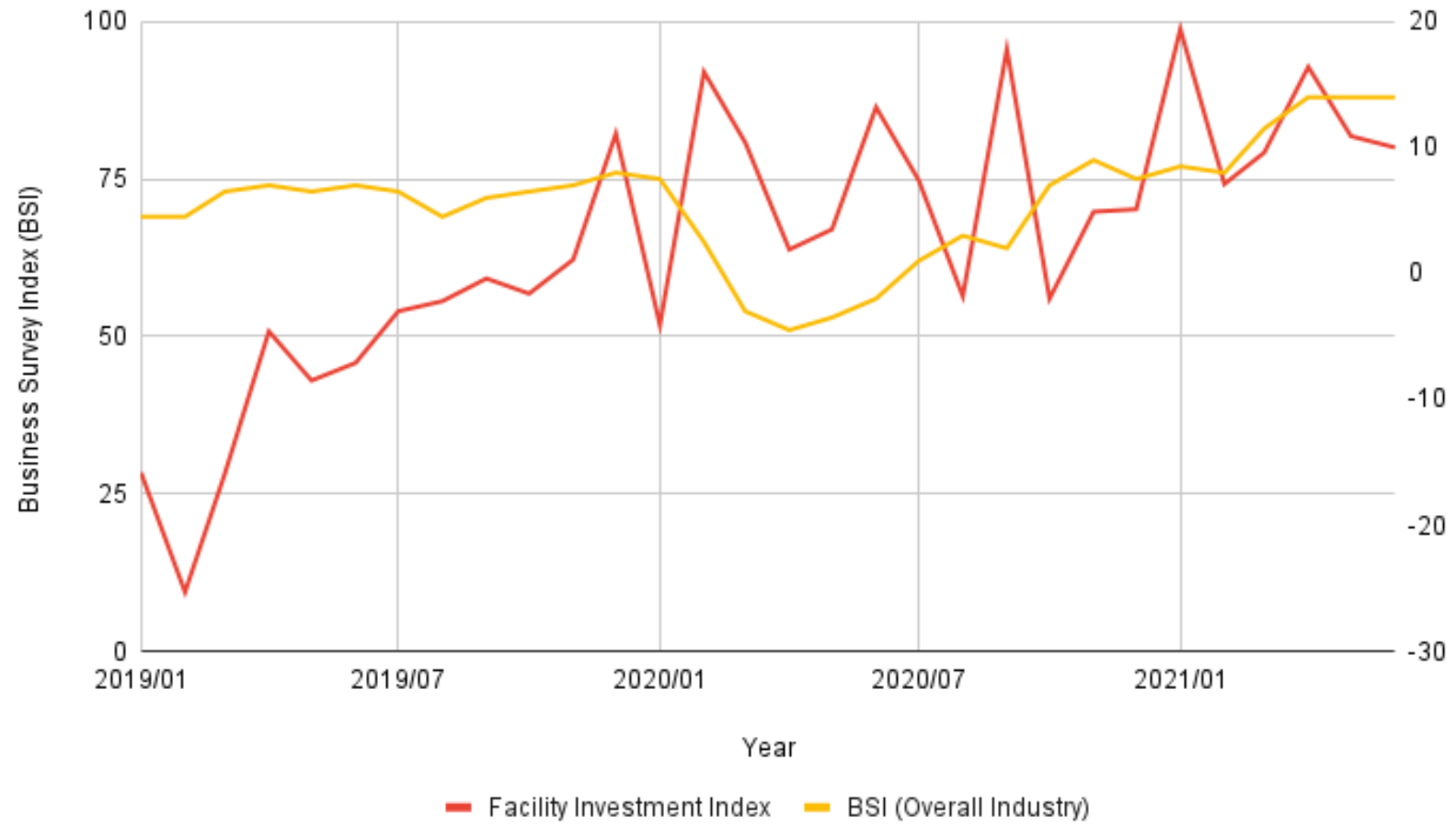


Figure 4. Business Confidence and Facility Investment Index during the COVID-19 Recession. The yellow line graph represents the BSI for overall industry, and the red line graph represents the facility investment index.

Data from the Bank of Korea Economic Statistics System, 2021.

This lack of crowding out can be attributed to not only the BOK's monetary policy of setting the base rate to a record-level of $0.5 \%$ but also to other factors. According to the KIET (2021), the increase in facility investment can suggest that firms are viewing the current crisis as a temporary phenomenon. To support this claim, in February 2020, President Moon assured the representatives of Korea's leading firms that the government will do everything in its power to terminate COVID-19 soon and asked the firms to trust the government and execute their facility investment as planned. Another factor driving up investment could be that firms learned from previous crises that investing during an economic crisis leads to an enhanced competitiveness in the market after the crisis. According to a recent article from McKinsey (2021), firms that invested in innovation during the GFC not only emerged more strongly from the crisis than their competitors but also fared better in the post-crisis period. Furthermore, a factor that could have helped prevent the crowding out effect during the current crisis is Korea's aging population. Research by the BOK (Kwon \& Kim, 2020) found that Korea's aging population contributed to the steady decline in real interest rates in recent years; as the average life expectancy increases, people are more likely to save for their post-retirement lives. Thus, the aging population could have countered the effect of the expansionary fiscal policies by preventing the real interest rate from rising too high.

\section{Conclusion}

The cross-time case comparison of the GFC and COVID-19 shows that, ultimately, the Korean government's expansionary fiscal policies did not crowd out business investment. Although the facility investment index did decrease during the GFC, further analysis makes it clear that this decrease was due to factors other than the fiscal policies. One possible such factor is the decreased business confidence, as firms theoretically cut their investment spending when they expect a lower return. This research sheds light on the aptness of using fiscal policy as a countercyclical tool by ruling out the crowding out effect as a potential concern. This paper also contributes to the existing literature on crowding out by suggesting that it is not a concern during the GFC and COVID-19. To further explore the existence and scale of the crowding out effect, future research can investigate whether expansionary fiscal policy implemented during an economic expansion (when the economy is producing at its potential output level) causes the real interest rate to rise. Furthermore, to assess the viability of using fiscal policy to counter the impacts of a recession, studies can examine what effect the increase in budget deficit has on the economy in the long-term.

That being said, the COVID-19 crisis is still ongoing. Even though Korea's exports have returned to its precrisis level, President Moon announced in May that the government will continue its expansionary fiscal policies at least until 2022. His reasoning is that increased expenditure will not only help the economy fully recover from the recession but also help with the government debt: expansionary fiscal policies will increase the GDP in the following years and, in turn, increase the government's tax revenues. Unfortunately, a number of economists describe the President's argument as an "impossible conjecture." The Seoul National University professor Soyoung Kim stated that even if the expansionary fiscal policies succeed in increasing the national income, the possibility of that money returning as tax revenue is extremely slim (Jung, 2021). Hence, whether Korea's future actions in response to the pandemic crowds out private spending is yet to be determined. However, as this paper shows crowding out was not a negative effect of the fiscal policies pursued during the GFC and COVID-19. By examining the past, this paper hopes to provide actionable insights for fiscal policymakers' future decisions.

\section{Acknowledgments}


I would like to acknowledge the Lumiere Education for providing helpful guidance and feedback. I would especially like to thank my mentor, Emma Campbell-Mohn, who helped me successfully navigate through the research process.

\section{References}

1918 Pandemic (H1N1 virus). (2019, March 20). Retrieved from https:/www.cdc.gov/flu/pandemic-resources/1918pandemic-hln $1 . h \mathrm{~m}$ l

Am, J., Furstenthal, L., Jorge, F., \& Roth, E. (2021). "Innovation in a crisis: Why it is more critical than ever." McKinsey \& Company.

Bank of Korea Economic Statistics System. https://ecos.bok.or.kr/

Blanchard, O. (2008). "Crowding out," The New Palgrave Dictionary of Economics, 2nd Edition.

Cho, D., \& Kim, H. (Eds.). (2011). Korea's Capacity to Cope with Crises in a Globalized Environment. Korea Development Institute, 2011(03).

Chung, H. (2021, November). 現 정 부 의 발 상 은 '우 리 에 게 내 일 은 없다 는 것' (The Idea of the Current Government is that "there is no tomorrow for us"). 월 간 조 선 (Monthly Chosun Magazine).

Ferguson, C. (Producer and Director). (2010). Inside Job [Motion picture]. United States: Sony Pictures Classics.

Financial Crisis Inquiry Commission. (2011). The Financial Crisis Inquiry Report.

https:/www.govinfo.gov/content/pkg/GPO-FCIC/pdf/GPO-FCIC.pdf

Friedman, M., \& Heller, W. W. (1969). Monetary vs. fiscal policy. Norton.

Heo, C., Ahn, S., \& Kim, C. (2009). 글 로 벌 금 응 위 기 의 파 장 과 대 응 방 안 (The Impact of the Global Financial Crisis and Countermeasures). Korea Economic Research Institute (KERI) Policy Research.

Herndon, T., Ash, M., \& Pollin, R. (2013). Does high public debt consistently stifle economic growth? A critique of Reinhart and Rogoff. Cambridge Journal of Economics, 38(2), 257-279. doi:10.1093/cje/bet075

International Monetary Fund (2009, January). World Economic Outlook.

International Monetary Fund, Asia and Pacific Dept. (2021). Republic of Korea: 2021 Article IV Consultation -Press Release; Staff Report; Staff Statement; and Statement by the Executive Director for the Republic of Korea. (Country Report No. 2021/064).

Jang, T. (2020). Trend and Cause Analysis of Investment in South Korea after the Global Financial Crisis. Ordo Economics Journal, 23(3), 43-62. doi:10.20436/oej.23.3.043

Jung, U. (2021, May 30). "경 제 학 적 으로 불 가 능 "...文 대 통 령 주 장 에 전 문 가 들 '반 박 ' ("Economically Impossible"... Experts Rebut to President Moon's Claim). 한 국 경 제 (The Korea Economic Daily). https://ww.hankyung.com/economy/article/202105281246i. 
Keeley, B., \& Love, P. (2010). From Crisis to Recovery. OECD Insights. doi:10.1787/9789264077072-en

Keynes, J. M. (1936). The General Theory of Employment, Interest and Money. Wirtschaft u. Finanzen.

Kim, Kihwan (2006, July 10-11). The 1997-87 Korean Financial Crisis: Causes, Policy Response, and Lessons [Conference presentation]. The High-Level Seminar on Crisis Prevention in Emerging Markets Organized by the International Monetary Fund and the Government of Singapore.

Korea Development Institute (KDI). (2021). KDI Economic Outlook (Vol. 38 No. 1)

Korea Economic Research Institute (KERI). (2020). 주요 경제 위기와 현재 위기의 차이 점과 향후 전망 (Differences between Major Economic Crises and the Current Crisis and Future Prospects). KERI Insight (No. 20$04)$.

Korea Institute for Industrial Economy \& Trade (KIET). (2020). 이 번 위기는 다 르 다: 코 로 나 발( 發) 경 제 위기 의 특 이성 과 정책 적 함의 (This Crisis is Different: the Specificity and Policy Implications of the COVID-19 Economic Crisis). (i-KIET Industrial Economy Issue No. 90).

Korea Institute for Industrial Economy \& Trade (KIET). (2021). 코로 나 팬데믹 이 후 1년의 한 국 경제: 경제 적 영 향의 중 간 평 가 (The Korean Economy One Year After the COVID-19 Pandemic: an Interim Evaluation of the Economic Impact). (i-KIET Industrial Economy Issue No. 109)

Krugman, P. (2009, May 31). Reagan Did It. The New York Times. https://www.nytimes.com/2009/06/01/opinion/01krugman.html

Kwon, O., \& Kim, M. (2020). 인구 고 령 화 가 실 질 금 리 에 미 치 는 영 향 (Impacts of Population Aging on Real Interest Rates). SSRN Electronic Journal. https://oi.org/10.2139/ssrn.3518163

Lee, T., Kim, M., Oh, Y., \& Lee, Y. (2021). 긴 급 재 난 지 원 금 지급 예 관 한 연구 II (A Study on the Emergency Coronavirus Relief Funds II). Korea Development Institute (KDI).

Makin, A. J., \& Layton, A. (2021). The global fiscal response to COVID-19: Risks and repercussions. Economic Analysis and Policy, 69,340-349. doi:10.1016/j.eap.2020.12.016

Mankiw, N. G. (2009). Principles of economics. Cengage Learning Asia Pte Ltd.

Mayer, C., Pence, K., \& Sherlund, S. (2008). The Rise in Mortgage Defaults. Federal Reserve Board, Washington, D.C. https://www.federalreserve.gov/pubs/feds/2008/200859/200859pap.pdf

McKay, A. (Director). (2015). The Big Short [Motion picture]. United States: Paramount Pictures Studios.

Ministry of Economy and Finance. (2020, October). 「월 간 재 정 동향 및 이슈 / (Vol. 81)

OECD. OECD Statistics. https://stats.oecd.org

Park, H. (2021). 추 경 편성 의 통 계 학 \& 경제 학 (Statistics \& Economics of Supplementary Budget Formation) (No. 2). K-Policy. 
Pyun, J. H., \& Rhee, D. (2014). Fiscal Multipliers During the Global Financial Crisis: Fiscal and Monetary Interaction Matters. SSRN Electronic Journal. doi:10.2139/ssrn.2333084

Reinhart, C., \& Rogoff, K. (2010). Growth in a Time of Debt. doi:10.3386/w15639

Seol, Y., \& Kim, C (2011). 글로 벌 금 융 위기 이후 총고정 투 자 추이 와 성장 기 여도 (Total Fixed Investment Trend and Growth Contribution After the Global Financial Crisis). (KERI Brief 11-15).

Slow jobs recovery and increased inequality risk long-term COVID-19 scarring. (2021, June 02). Retrieved from https:/www.ilo.org/global/about-the-ilo/new sroom/news/WCMS 794834/lang--en/index.htm

"Transcript: Ezra Klein Interviews Paul Krugman About Our Covid Economy." The New York Times, The New York Times, 4 Feb. 2021, www.nytimes.com/2021/02/04/podcasts/ezra-klein-podcast-paul-krugman-transcript.html

A UN Framework for the Immediate Socio-economic Response to COVID-19. (2020). UN Executive Office of the Secretary-General (EOSG) Policy Briefs and Papers. doi:10.18356/420812ce-en

World Trade Organization (WTO) Data. https://data.wto.org/ 